\title{
An Analytic Hierarchy Process-based Study on the Organizational Commitment of Employees-- Taking the Miaoli County Fire Bureau as a Case Study
}

\author{
Chih-Yao Lo \\ Professor, Fo Guang University, Linwei Rd., Jiaosi, Taiwan (R.O.C.) \\ cylo@mail.fgu.edu.tw
}

\section{Hsiang-Ying Shen}

Associate Professor, Yu-Da University of Science and Technology, Hsueh-fu Rd., Tanwen Village, Chaochiao Township, Miaoli County, Taiwan, (R.O.C)

yd2935@ydu.edu.tw

\section{Ching-Yao Luo}

Postgraduate, Yu-Da University of Science and Technology, Hsueh-fu Rd., Tanwen Village, Chaochiao Township, Miaoli County, Taiwan, (R.O.C)

luochingyao@gmail.com

\begin{abstract}
As the disasters in urban areas become more diverse and widespread, firefighters have been facing an increasingly complicated work environment and are hence confronted with pressure, which will reduce their organizational commitment, affect their service quality, slow down their work, and even force them to resign and cause problems in organizational operation.

To define the decision-making reference basis that influences the organizational commitment of the employees of Miaoli County Fire Bureau, this study collected relevant academic documents at home and abroad, undertook the Modified Delphi Method-based questionnaire, established the decision-making hierarchical framework of the organizational commitment of the employees, and finally used the Analytic Hierarchy Process to obtain the relative weights of the factors.

According to the analysis and induction in this study, the factor weights were first "work feature" and then "service professionalism and labor division". If improvement is achieved in the systematic aspect of "labor division of service and professionalism of firefighting", it will enhance firefighters' professional knowledge and skills and achievement motivation of firefighters and then increase their organizational commitment. The author hopes that the factor weights analyzed and induced in this study will help the employees of the bureau develop a positive attitude towards work and assist the institution promote organizational commitment.
\end{abstract}

Keywords: organizational commitment, Analytic Hierarchy Process, Modified Delphi Method, Miaoli County Fire Bureau

\section{INTRODUCTION}

The reduction in organizational commitment would result in problems in organizational operation. According to The Organization Man, "Organization men not only work for the organization but also belong to the organization" (Whyte,1956)[1]. Organizational commitment influences employees' work efficiency and their attitude toward work. Strong organizational commitment means that employees have a strong sense of identity for the organization, which is a favorable factor for the organization. Therefore, this study applied the Analytic Hierarchy Process (AHP) and the Modified Delphi Method-based questionnaire to elucidate the factors influencing the organizational commitment of employees and the relative weights of these factors, taking the Miaoli County Fire Bureau as a case study. 


\section{LITERATURE REVIEW}

AHP is a decision-making method proposed by Professor T. L. Saaty from University of Pittsburgh in the 1970s and is mainly applied to the decision-making problems that involve various evaluative norms. According to Saaty[1], AHP can be applied in the following 12 fields: Setting Priorities, Generating a set of alternatives, Choosing a best policy alternatives, Determining requirements, Allocating resources, Predicting outcomes/Risk assessment, Measuring performance, Designing system, Ensuring system stability, Optimization, Planning, and Resolving conflict.

Delphi method was first proposed by the US Rand Corporation in 1948, and this is the first application in Defence Research sponsored by the US Air Force. It was a method applied to speculate the future by collecting opinions from experts. It was an anonymous way by writing for experts to express their thoughts on a subject without meeting one another. Each time the result of survey would be analyzed to be a reference for the amendments from experts and scholars; many questionnaires were created to survey until experts' advice was achieved convergence. To avoid time consuming and might be restricted by funding and human resources, Delphi was modified so that the research could be carried out smoothly in the process. The revised way was called Modified Delphi Method [2].

According to the academic documents, the factors influencing organizational commitment can be roughly divided into three dimensions -- "personality trait", "personal attribute" and "organizational factor", which are described in detail as follow:

\subsection{Personality Trait}

"Personality trait" can explain the reasons for a person's behaviors, for a person's values and preference are often reflected in his/her personality and trait, and a person's personality often influence his/her work conduct (Liao, 2001)[3].

According to the five-factor theory of Norman (1963)[4] and on the basis of the previous studies of Costa and McCrae[5], this study adopted the Big Five Theory, currently accepted by most personality psychology scholars, and took five personality traits -- "neuroticism", "extraversion", "openness", "agreeableness" and "conscientiousness" as the decision-making factors that influence the organizational commitment of the employees of the bureau.

\subsection{Personal Attribute}

The resultant variables of organizational commitment proposed by Porter, Steers, Mowday and Boulian (1974) [6] included "performance" and "attendance"; the ones by Steers (1977) [7] included "retention intention", "performance" and "attendance"; the ones by Stevens, Beyer \& Trice (1978)[8] included "retention intention" and the variables that aimed to enhance organizational commitment. The objective of this study is related to the above scholars' theories on the resultant variables of organizational commitment, so this study classified the factors of antecedent variables into "work feature", "work experience", "educational level", "gender", "age", "length of service" and "organizational factor" according to the theoretical models of the above scholars and took them as the decision-making factors that influenced organizational commitment of the employees of the bureau.

\subsection{Organizational Factor}

Willoughby (1927: 298)[9] argued that an appropriate talent promotion system could increase civil servants' passion for service and that there should be correlation between the promotion system and organizational performance. Moreover, the allowance for firefighters and the concern for them also had direct effects on their trust in and passion for work. The benefits for firefighters can be divided into group and personal ones (Chen, 2003, Fire Science) [10], which are also connected with organizational factors. According to the above scholars' discussions on organizational factor and relevant domestic decrees, this study classified organizational factors into "national exam system", "internal promotion system", "demand system", "incentive", "allowance" and "employee benefit 
system" and took them as the decision-making factors that influenced the organizational commitment of the employees of the bureau.

\section{RESEARCH METHOD}

The research topic of this study was defined according to the research background and motivation. The Modified Delphi Method and the AHP were used to discuss the factors that influence the organizational commitment of employees. The research subjects consisted of two groups:

1. The respondents of the expert questionnaire

The Modified Delphi Method was used for the semi-open expert questionnaire. In this study, 16 experts were invited, including 4 directors, 4 commanders, 4 internal work members and 4 external work members of the bureau.

2. The respondents of the AHP questionnaire

The research subjects were the employees of the Miaoli County Fire Bureau, and with "age" and "position" as the variables in the hierarchical random sampling, they filled in the questionnaire copies according to the designated instruction.

In this study, the Modified Delphi Method and the AHP were employed to elaborate on the factors that influenced the organizational commitment of the employees of the Miaoli County Fire Bureau. The research procedure is shown in Figure 1, and the research steps are as follow:

\section{Literature Review}

Got acquainted with the Modified Delphi Method and the AHP and collected the theories and studies on organizational commitment to make a preliminary analysis of the factors that influenced the organizational commitment of the employees of the Miaoli County Fire Bureau.

2. Used the Modified Delphi Method to establish the decision-making hierarchy framework

Applied the Modified Delphi Method to the semi-open expert questionnaire and evaluated the expert views until convergence to establish the decision-making hierarchy framework.

3. Adopted the AHP to analyze the relative weights of the factors that influenced the organizational commitment of the employees of the Miaoli County Fire Bureau.

The description of the implementation of the AHP research steps is as follow:

- Developed the AHP questionnaire and delved into the importance of the factors that influenced the organizational commitment of the employees of the Miaoli County Fire Bureau.

- Retrieved the questionnaire copies for the statistical analysis; compared the single-layer factors in the decision-making hierarchical framework; compared the evaluative factors on the evaluation item layer.

- Established the paired comparison matrix.

- Calculated the feature vectors.

- Demonstrated the consistency.

- Calculated the weights of the overall evaluative factors to know the relative importance-based ranking of the factors that influenced the organizational commitment of the employees of the Miaoli County Fire Bureau.

4. Analysis of and discussion on the empirical results

5. Conclusion and discussion 


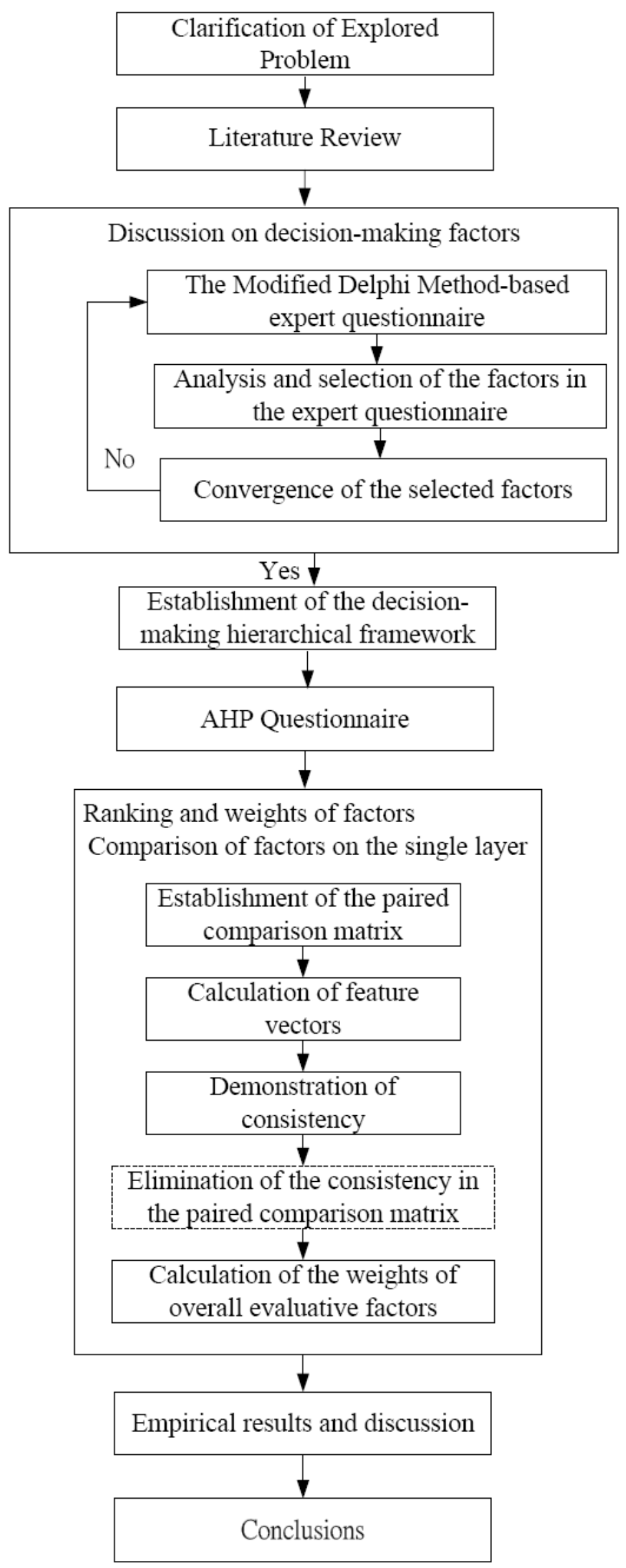

Figure1. Research Flowchart 


\section{DEVELOPMENT OF DECISION FRAMEWORK}

According to the literature review, the possible factors that influenced the organizational commitment of the employees of the Miaoli County Fire Bureau: "personal attribute", "organizational factor", and "personality trait". "Personal attribute" included "work feature", "educational level", "work experience", "gender", "age" and "position"; "organizational factor" comprised "national exam", "internal promotion system", "demand system", "incentive", "allowance" and "employee benefit system"; "personality trait" consisted of "neuroticism", "extraversion", "openness", "agreeableness" and "conscientiousness".

Then, the Modified Delphi Method was used for the expert questionnaire, so as to confirm the appropriateness of the preliminary evaluation item. In the first round, the questionnaire retrieval rate was 100\%; the expert support for all the selected factors was over $85 \%$; but the the expert support for "educational level", "gender", "position", "national exam" and "neuroticism" in the evaluation item was lower than $70 \%$. Therefore, these five evaluative factors were removed from this study, and the remaining 11 preliminary evaluative factors were used for the decision-making hierarchical framework in the study.

Additionally, the experts gave many valuable views according to the open questions in the expert questionnaire in the first round. The views are as follow:

1. As far as "personal attribute" was concerned, "educational level", "gender" and "position" didn't influence the experts in the organizational commitment of the fire bureau, and the similarity of these three factors was as follow: the fire bureau was a state unit and its employees were recruited through the national exam; despite the difference in educational level among them, they all had some professional knowledge and skills, so educational level could not reflect the organizational commitment of the employees; the gender of the employees of the fire bureau could not determine their efficiency and passion for work; all the positions for the employees were significant and special. Therefore, the experts believed that the above three factors did not have direct effects on the employees' organizational commitment for the organization.

2. In terms of "organizational factor", the experts thought that "national exam" did not influence the organizational commitment of the fire bureau, for national exam was one of national policies and a system for the recruitment of the fire bureau. Passing the national exam was a requirement and should not be taken as a factor that influenced the organizational commitment of the employees.

3. According to other experts, "length of service", "service professionalism and labor division", "familial factor" and "physical fitness" were also the factors that influenced the organizational commitment of the fire bureau.

According to the above investigation results, the four evaluative factors proposed by some experts, including "length of service", "service professionalism and labor division", "familial factor" and "physical fitness", still entail further review of all experts, so as to make sure if it is appropriate to add the four factors onto the evaluation item layer.

To develop the expert questionnaire of the second round and facilitate the convergence of the final views of the experts, the meaning of the four factors -- "length of service", "service professionalism and labor division", "familial factor" and "physical fitness" proposed by some experts is summarized as follow:

1. "Length of service". Stevens, Beyer \& Trice (1978) proposed such a theory: in the initial stage of career, the organizational commitment of organization members was influenced by psychological or personal factors; with the increase in length of service, additional interest gradually to create effects and hence the organization received some commitment from its members.

2. "Service professionalism and labor division". The exclusive security team, the special search team, and the exclusive rescue team of the organization hope to expand the professional knowledge and skills and achievement motivation of employees through professionalism and labor division.

3. "Familial factor". According to the focuses of Taiwan's fire service, the daily service period is 24 hours; such a work feature makes it hard for the employees to keep a balance in time distribution between work and family, which inevitably affect the employees' passion for work. 

the Miaoli County Fire Bureau as a Case Study

4. "Physical fitness". The fire bureau makes criteria to test if the firefighters maintain their physical fitness according to the criteria on a regular basis. "Physical fitness" counts more in firefighting than in other civil work environments.

According to the above meaning, this study incorporated "length of service", "familial factor" and "physical fitness" into "personal factor"; "service professionalism and labor division" was added into "organizational factor". The retrieval rate of the expert questionnaire of the second round was $100 \%$. According to the statistics about support, the newly-added four evaluation items were also supported by other experts and were converged. Therefore, the factors that influenced the organizational commitment of the employees of the Miaoli County Fire Bureau were divided into three dimensions in the form of 15 evaluation items.

According to the research need, the "Typical AHP Structure" was used to design the decision-making hierarchical framework of this study [11]. The developed "Decision-making Hierarchical Framework" is as follow:

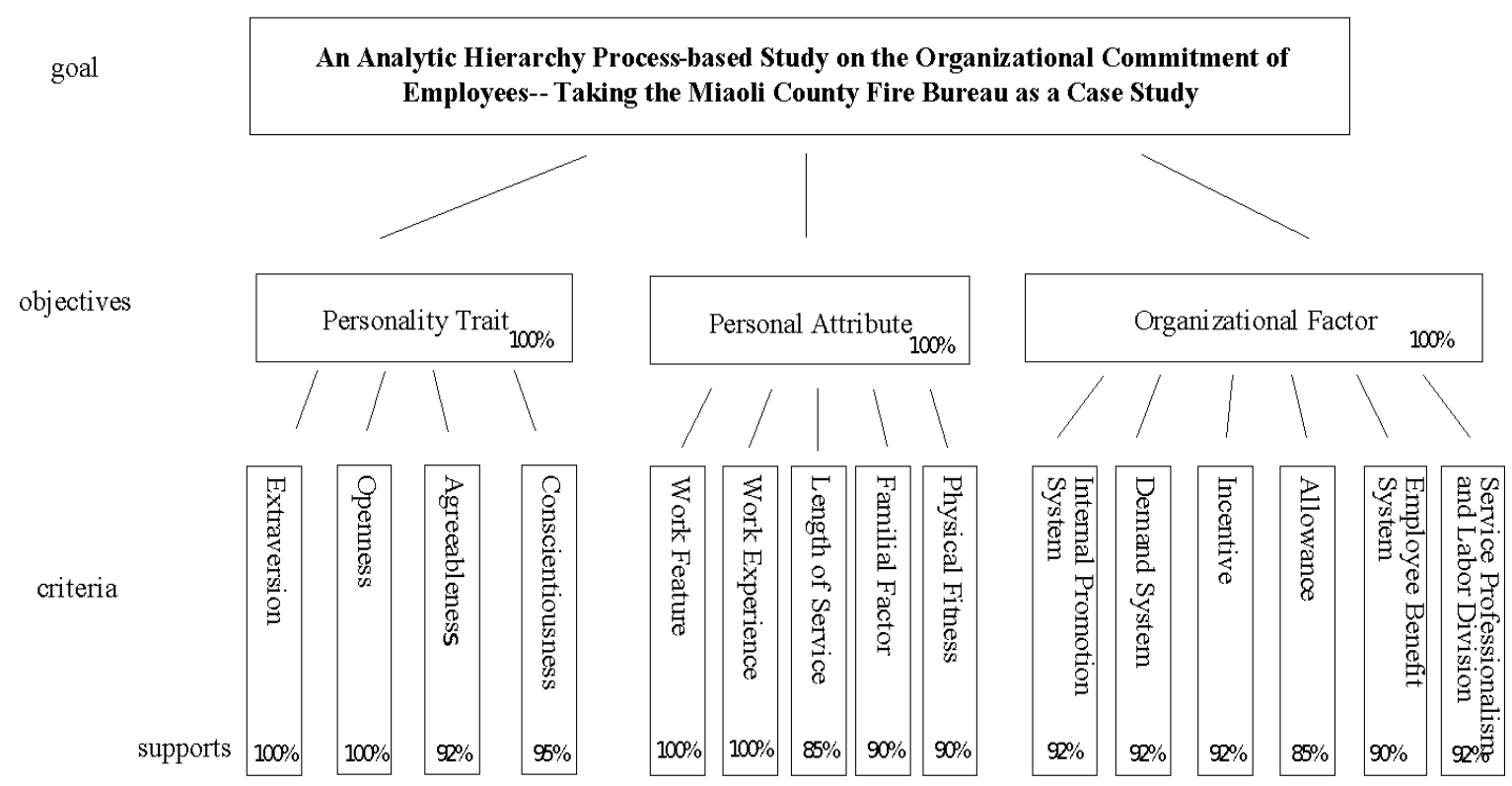

Figure2. Decision-making Hierarchical Framework

Table1. Description of the Meaning of Evaluation Items

\begin{tabular}{|c|c|c|}
\hline \multicolumn{2}{|c|}{ Factors in Consideration } & Description of Meaning \\
\hline \multirow[t]{4}{*}{$\begin{array}{l}\text { Personality } \\
\text { Trait }\end{array}$} & Extraversion & $\begin{array}{l}\text { The comfort about the relationship with others. Features: confident, } \\
\text { active, passionate about making friends and participating in popular } \\
\text { activities. }\end{array}$ \\
\hline & Openness & $\begin{array}{l}\text { The absorption of facts and new things. Features: open-minded, full } \\
\text { of imagination, curious and eager for something new. }\end{array}$ \\
\hline & Agreeableness & $\begin{array}{l}\text { The personality trait of getting well with others and easy to } \\
\text { communicate and cooperate. Features: polite, reliable, friendly, easy } \\
\text { to get along, and tolerant. }\end{array}$ \\
\hline & Conscientiousness & $\begin{array}{l}\text { A person's concentration of pursuing objectives. Features: hard- } \\
\text { working, success-oriented, disciplined, meticulous, and responsible. }\end{array}$ \\
\hline \multirow[t]{4}{*}{$\begin{array}{l}\text { Personal } \\
\text { Attribute }\end{array}$} & Work Feature & $\begin{array}{l}\text { Work content, workplace, feedback of work, independence, skill, } \\
\text { future, internal reward, and self achievement. }\end{array}$ \\
\hline & Work Experience & $\begin{array}{l}\text { Group's attitude towards the organization, the reliability of the } \\
\text { organization, work expectation, the organization's focus on } \\
\text { individuals, and satisfaction. }\end{array}$ \\
\hline & Length of Service & $\begin{array}{l}\text { In the initial stage of career, the passion for work can enhance the } \\
\text { solidarity of the organization; with the increase in the length of } \\
\text { service, senior employees face additional interest and other outside } \\
\text { factors, which may have direct effects on their passion for work. }\end{array}$ \\
\hline & Familial Factor & $\begin{array}{l}\text { Currently, according to the focuses of Taiwan's fire service, the daily } \\
\text { service period is } 24 \text { hours; such a work feature makes it hard for the }\end{array}$ \\
\hline
\end{tabular}




\begin{tabular}{|c|c|c|}
\hline & & $\begin{array}{l}\text { employees to keep a balance in time distribution between work and } \\
\text { family, which inevitably affect the employees' passion for work. }\end{array}$ \\
\hline & Physical Fitness & $\begin{array}{l}\text { Firefighting is a job that requires physical fitness and skills; check the } \\
\text { physical fitness of firefighters on a regular basis; the results of the } \\
\text { test are related to the reward for work and promotion. }\end{array}$ \\
\hline \multirow[t]{6}{*}{$\begin{array}{l}\text { Organizational } \\
\text { Factor }\end{array}$} & $\begin{array}{l}\text { Internal } \\
\text { Promotion } \\
\text { System }\end{array}$ & $\begin{array}{l}\text { Promotion refers to the position adjustment of the in-service } \\
\text { employees in the current institution or transfer to other institutions; } \\
\text { the duties increase, or position rises, or benefits increase. }\end{array}$ \\
\hline & Demand System & $\begin{array}{l}\text { Attach equal importance to fire service, help firefighters transfer to } \\
\text { the demanded service areas, adapt to new work and a new life, and } \\
\text { establish a demand system. }\end{array}$ \\
\hline & Incentive & $\begin{array}{l}\text { To motivate firefighters and enhance their work efficiency, incentives } \\
\text { are awarded to those who have special contribution. }\end{array}$ \\
\hline & Allowance & $\begin{array}{l}\text { The rights and interests for the Taiwanese firefighters because of the } \\
\text { dangerous position are a topic attracting the attention of firefighters } \\
\text { and have direct effects the employees' trust in and passion for their } \\
\text { work. }\end{array}$ \\
\hline & $\begin{array}{l}\text { Employee Benefit } \\
\text { System }\end{array}$ & $\begin{array}{l}\text { It can be divided into two aspects -- group and individual, including } \\
\text { the facilities in dormitories. As for personal benefits, offer the } \\
\text { insurance of injury and disease for firefighters. }\end{array}$ \\
\hline & $\begin{array}{l}\text { Service } \\
\text { Professionalism } \\
\text { and } \\
\text { Labor Division }\end{array}$ & $\begin{array}{l}\text { The exclusive security team, the special search team, and the } \\
\text { exclusive rescue team of the organization hope to expand the } \\
\text { professional knowledge and skills and achievement motivation of } \\
\text { employees through professionalism and labor division. }\end{array}$ \\
\hline
\end{tabular}

\section{EMPIRICAL STUDY AND RESULTS ANALYSIS}

With the AHP and according to the decision-making hierarchical framework, this study developed an AHP questionnaire for the employees of the fire bureau. The judgment of the employees was collected through the questionnaire. The respondents were 35 internal external service units in 18 towns under the jurisdiction of the Miaoli County Fire Bureau. In the process, 35 questionnaire copies were distributed, and 25 of them were retrieved, including an invalid one (two answers were circled for each item). The number of valid questionnaire copies was 24 , with a retrieval rate of $71 \%$. Of the 24 questionnaire copies, 13 were filled by average employees and 11 by managerial employees; 10 were filled by those aged from 20 to 30,8 by those aged from 30 to 40 , and 6 by those aged over 40 .

After the results of the filled questionnaire copies were converted into a quantified scale, it was possible to establish a paired comparison matrix for each evaluation factor and each scheme. The rating value in each matrix was a geometrical average.

Table3. The Decision-making Reference Indexes of the Factors that Influenced the Organizational Commitment of the Employees of the Miaoli County Fire Bureau and the Ranking of These Indexes

\begin{tabular}{|c|c|c|c|c|c|}
\hline $\begin{array}{l}\text { Index Dimension } \\
\text { (Sub-objective Layer) }\end{array}$ & $\begin{array}{l}\text { Dimension } \\
\text { Weight }\end{array}$ & $\begin{array}{l}\text { Index } \\
\text { (Evaluation Item Layer) }\end{array}$ & $\begin{array}{l}\text { Index } \\
\text { Weight }\end{array}$ & $\begin{array}{l}\text { Overall } \\
\text { weight }\end{array}$ & Ranking \\
\hline \multirow[t]{4}{*}{ Personality Trait } & \multirow[t]{4}{*}{0.279} & Extraversion & 0.386 & 0.108 & 2 \\
\hline & & Openness & 0.315 & 0.088 & 4 \\
\hline & & Agreeableness & 0.145 & 0.040 & 12 \\
\hline & & Conscientiousness & 0.154 & 0.043 & 11 \\
\hline \multirow[t]{5}{*}{ Personal Attribute } & \multirow[t]{5}{*}{0.301} & Work Feature & 0.466 & 0.140 & 1 \\
\hline & & Work Experience & 0.277 & 0.083 & 6 \\
\hline & & Length of Service & 0.067 & 0.020 & 15 \\
\hline & & Familial Factor & 0.104 & 0.031 & 13 \\
\hline & & Physical Fitness & 0.086 & 0.026 & 14 \\
\hline \multirow[t]{6}{*}{ Organizational Factor } & \multirow[t]{6}{*}{0.420} & Internal Promotion System & 0.200 & 0.084 & 5 \\
\hline & & Demand System & 0.196 & 0.082 & 7 \\
\hline & & Incentive & 0.163 & 0.068 & 8 \\
\hline & & Allowance & 0.111 & 0.047 & 10 \\
\hline & & Employee Benefit System & 0.121 & 0.051 & 9 \\
\hline & & $\begin{array}{l}\text { Service Professionalism and } \\
\text { Labor Division }\end{array}$ & 0.210 & 0.088 & 3 \\
\hline
\end{tabular}


After the weight vectors of the paired comparison matrix were obtained and all met the requirement on consistency, the relative weights of the overall hierarchical evaluation items were calculated, and the evaluative factors were ranked. Table 3 shows the decision-making reference indexes of the factors that influenced the organizational commitment of the employees of the Miaoli County Fire Bureau and the ranking of these indexes.

According to the above results of calculation, the indexes of "organizational factor" had the greatest effects among the factors that influenced the organizational commitment of the employees of the Miaoli County Fire Bureau, followed by "personal attribute" and "personality trait".

As for the overall evaluation indexes, "work feature" created the greatest effects among the factors that influenced the organizational commitment of the employees of the Miaoli County Fire Bureau, followed by "extraversion", "service professionalism and labor division", "openness", "internal promotion system", "work experience", "demand system", "incentive", “employee benefit system", "allowance", "conscientiousness", "agreeableness", "familial factor", "physical fitness" and "length of service".

\section{CONCluSion AND Suggestions}

This study targeted the employees of the Miaoli County Fire Bureau, and the factor weight ranking was analyzed, which were inapplicable to other regions. There may be different views on the relative importance of the evaluation items due to different regional features and folk customs, which would lead to different effects of organizational commitment factors. Despite this, even if the decisionmaking results obtained with the AHP could not represent the best framework weight, it was closest to the ideal value and provided decision-makers with better decisions. Therefore, the best decisionmaking indexes of the factors that influenced the organizational commitment of the employees can still serve as reference for the Miaoli County Fire Bureau in its efforts to enhance the organizational commitment of its employees.

According to the analysis of the decision-making indexes of the factors that influenced the organizational commitment of the employees of the Miaoli County Fire Bureau, this study gives the following suggestions: with the Modified Delphi Method-based expert questionnaire and the AHP, this study the top 2 dimensions in the weight of main norms were "organizational factor" and "personal attribute", whose factor weights were "work feature" and "service professionalism and labor division"; as for the factors of "work feature" which ranked the first in the overall weight, the honorable sense of mission of firefighting made firefighters focus on internal reward and selfachievement, improve work skills, accumulate experience, strengthen the ability to handle crisis, and hope to make contribution in firefighting. The prospect of firefighting and the planning of career development are also very important. In terms of "service professionalism and labor division", fire prevention, fire relief and emergent aid are the three main tasks of firefighting, which are the basis for the organizational preparation of the government and the arrangement of firefighting service. The exclusive security team, the special search team, and the exclusive rescue team of the organization aim to improve the service and work of firefighting through professionalism and labor division. Currently, the Taiwan's firefighters have to handle various complicated tasks beyond their duties, such as rescuing trapped cats and dogs, removing trees on roadsides, cleaning roads, lifting dropped billboards. These tasks have undoubtedly expanded the meaning of serving people and resulted in the abuse of firefighting resources. Therefore, it is necessary to return to professional firefighting and provide firefighting resources to those who need it most. According to the decision-making index weight of the employees' organizational commitment hierarchical framework, if it is possible to "return to professional firefighting" and achieve "fire service professionalism and labor division", the employees of the fire bureau will be able to enhance their professional knowledge and skills, and increase achievement motivation. Moreover, it will increase the organizational commitment of the employees of the Miaoli County Fire Bureau and then create social benefits. 


\section{REFERENCES}

[1] Saaty, T. L. (1990). The Analytic Hierarchy Process, RWS Publications, Pittsburgh, PA.

[2] Li, L.S. (1999). America's Ability-based Course Development Model. Employment and Training, 37-45.

[3] Liao, C.L., “An Exploratory Study on Employees' Personality Trait, Attitude Towards Money, Work Performance, and Dismissal". Taoyuan, master's thesis, Graduate Institute of Business and Management, Chang Gung University (unpublished), 2001.

[4] Norman, W. T., Toward and Adequate Taxonomy of Personality Attributes: Replicated Factor Structure. Journal of Abnormal and Social Psychology, 66, 574-583., 1963.

[5] McCrae, R. R., and Costa, P. T. Jr., Validation of The Five-Factor Model of Personality Across Instruments and Observers. Journal of Personality and Social Psychology, 52, 81-90., 1987.

[6] Mowday, R.T., Porter, L.W., \&; Steers, R.M, Employee-Organization Linkages: The Psychology of Commitment, Absenteeism, and Turnover. New York, NY: Academic Press., 1974.

[7] Steers, R.M, Antecedents and outcomes of organizational commitment, Administrative Science Quarterly, 22, 46-56., 1977.

[8] Stevens, J. M., Beyer, J. M., \& Trice, H. M.,Assessing personal, role, and organiza-tional predictors of managerial commit-ment, Academy of Management.Journal, 21, 382.,1978.

[9] Willoughby, W. F.,Principle of Public Administration. Baltimore: John Hopkins.,1927.

[10] Chen, H.Y., "Fire Science", Taipei: Tingmao Publish,2003.

[11] Teng, C.Y. and Tseng, K.H. (1989). Meaning, Feature and Application of Analytic Hierarchical Process (AHP) (I) (II). China Statistics Journal. Taipei: Periodical Office of China Statistics Journal. 